$1^{\text {st }}$ International Multidisciplinary Conference on Nutraceuticals and Functional Foods

Current Research in Nutrition and Food Science

Vol. 4(SI. 2), 133-137 (2016)

\title{
Production of Traditional Cheese Coagulant in Farmhouse and Coagulating Effect
}

\author{
DILEK SAY ${ }^{1 *}$ and NURAY GUZELER ${ }^{2}$ \\ ${ }^{1}$ Vocational School of Pozanti, Cukurova University, Adana, Turkey. \\ ${ }^{2}$ Department of Food Engineering, Faculty of Agriculture, Cukurova University, Adana, Turkey.
}

http://dx.doi.org/10.12944/CRNFSJ.4.Special-Issue-October.18

(Received: August, 2016; Accepted: September, 2016)

\begin{abstract}
Milk-clotting enzymes are the primary active agents in the manufacture cheeses. Animal rennet, microbial coagulant and plant coagulant are used as milk coagulants in cheese making. However, alternative milk coagulants are investigated instead of animal enzymes due to slaughtering of young ruminant. Manufacturing of milk clotting enzyme in farmhouse have been employed successfully for many centuries in Mediterrenean region and Toros mountain villages of Turkey for the production of traditional Tulum cheese. Figs, raisins, white beans, chickpeas, carob, granulated sugar, salt, yoghurt and home-made rennet (sarkanak) are found in the content of this enzyme. This mixture is left at room temperature for 5-6 days. The enzyme is filtered from using cloth bag and added into milk for coagulation. In this research; chemical composition of cow's milk, goat's milk and ewe's milk were determined and obtained enzymes from different manufacturers were investigated of clotting effects on cow's milk, goat's milk and ewe's milk. Four different coagulants had a strong coagulating effect on raw and pasteurized ewe's milk. The highest milk clotting activity of all coagulant samples were seen in ewe's milk, followed by cow's milk and goat's milk.
\end{abstract}

Keywords: Cow's milk, goat's milk, ewe's milk, milk-clotting enzyme, cheese.

\section{INTRODUCTION}

Average total milk production in Turkey is around 18 million tons per year. Cow's milk provides $91.39 \%$ of it, $6.04 \%$ is ewe's milk and $2.28 \%$ is goat's milk ${ }^{1}$. Goat production in Mediterranean countries is particulary important under extensive conditions and ewe's milk with goat milk are consumed locally and processed delicious cheeses that are highly appreciated by the consumers. Their particular sensory characteristics are more preferred than cow's milk cheeses due to the composition of sheep and goat's milk².

Coagulation of milk is the main step in the manufacture of cheese and can be achieved by a number of proteolytic enzymes from various sources, such as different animal species, microbial proteinases and proteinases extracted from fruits and plants ${ }^{3}$. Calf rennet is still the most commonly used enzyme in cheese making. However, the increasing consumption of cheese and coupled with a world shortage of calf rennet have encouraged a search for alternative milk coagulants ${ }^{4,5}$.

In past times, the clotting enzyme was extracted from cleaned and air-dried stomachs by the cheese-maker. Dried vells are still available and solely used in artisanal cheese-making ${ }^{6}$. In Mediterranean region, especially Toros mountain villages, milk clotting enzyme for using production of Tulum cheese is directly manufactured in farmhouse. Figs, raisins, white beans, chickpeas, carob, granulated sugar, salt, yoghurt and home-made rennet which is salted and dried form are found in the content of this enzyme. This mixture is left at room 
temperature for 5-6 days. The enzyme is filtered from using cloth bag before cheese production. In traditional Tulum cheese production; the enzyme is added into raw milk for coagulation. 0,5-1 L enzyme is added into approximately $10 \mathrm{~L}$ milk. The obtained curd is mixed by salts and filled into tulum and pottery tightly but nowadays it mostly filled into plastic containers. The cheese is stored in natural caves of produced areas or at refrigerated conditions. The cheese is appreciated for high quality, exotic flavors and texture.

There are limited numbers of studies about coagulating effect on milk. To the authors' knowledge there is no information available of clotting effects on cow's milk, goat's milk and ewe's milk for this type coagulant. However, any comprehensive study on the use of plant and animal coagulant in cheese was found. The objective of this work was to determine chemical composition of cow's milk, goat's milk, ewe's milk and to study the coagulation of raw and pasteurized cow's milk, goat's milk and ewe's milk obtained coagulants from different manufacturers.

\section{MATERIALS AND METHODS}

Raw cow's milk, goat's milk and ewe's milk were obtained from the Animal Husbandry section of Cukurova University, Agricultural Faculty, Adana, Turkey. The coagulants, manufactured using a traditional procedure, were collected from four different farmhouses in Toros mountain villages of Turkey. The samples were kept in jars and transported to the laboratories at Food Engineering Departments at Cukurova University. Coagulant samples were stored at $4 \pm 1^{\circ} \mathrm{C}$ for analysis.

\section{Analyses \\ Chemical analyses}

The $\mathrm{pH}$ values were measured using a digital pH meter (WTW, Weilheim, Germany) in raw cow's milk, goat's milk and ewe's milk. Titratable acidity was determined by the alkali titration method' Total dry matter was determined by drying the samples in an oven at $100 \pm 5{ }^{\circ} \mathrm{C}^{8}$. Total milk fat content was determined by the Gerber method ${ }^{9}$. Protein was determined by the total nitrogen method of Kjeldahl ${ }^{10}$.

\section{Milk-clotting activity assay}

The milk clotting activities of the traditional cheese coagulant were determined according to TS 3844 for raw and pasteurized cow's milk, goat's milk and ewe's milk ${ }^{11}$. Briefly, $25 \mathrm{~mL}$ of assay milk was taken in a beaker and the contents were brought to $35^{\circ} \mathrm{C}$. Sample temperature was controlled using a water bath (Memmert). To this $1 \mathrm{~mL}$ of enzyme was then added and the curd formation was observed while manually rotating the beaker from time to time. The end point was recorded when discrete particles were discernible. For each experiment, the clotting time of the sample was measured three times and the average reported as the sample clotting time. The enzyme strength (ES) was defined as the number of volumes of coagulated milk clotted by one volume of rennet in $40 \mathrm{~min}$ at $35^{\circ} \mathrm{C}$. The calculation is: ES $=2400 \times \mathrm{V} / \mathrm{t} \times \mathrm{V}$, where, $\mathrm{V}$ one volume of milk $(\mathrm{mL}), \mathrm{t}$ the clotting time in seconds and $v$ equals one volume of coagulant $(\mathrm{mL})$.

\section{RESULTS AND DISCUSSION}

The results of the chemical analyses of cow's milk, goat's milk and ewe's milk are presented in Table 1.

Table 1 indicated that the mean values of cow's milk for $\mathrm{pH}$, titratable acidity, dry matter, fat, non-fat dry matter and protein contents were $6.77 \pm 0.01,0.18 \pm 0.01 \%$ (as lactic acid), $11.63 \pm$ $0.09 \%, 3.40 \pm 0.06,8.23 \pm 0.14 \%$ and $4.06 \pm 0.30 \%$, respectively. The cow's milk was within the reported mean values limits for titratable acidity (minimum $0.135 \%$, maximum $0.200 \%$ ) and protein (minimum $2.8 \%$ ) according to Turkish Standards for raw cow's milk $^{12}$. The dry matter, fat and non-fat dry matter content were found to be within acceptable levels for raw cow's milk.

The composition of goat's milk was as follows: $\mathrm{pH} 6.77 \pm 0.01,0.15 \pm 0.00 \%$ titratable acidity as lactic acid, dry matter $12.56 \pm 0.27 \%$, fat $3.83 \pm 0.06$, non-fat dry matter $8.73 \pm 0.22 \%$ and protein $4.26 \pm 0.04 \%$. The goat's milk was within the reported mean values limits for titratable acidity (minimum $0.15 \%$, maximum $0.28 \%$ ), non-fat dry matter (minimum 8.5\%) and protein (minimum 2.8\%) 
according to Turkish Standards for raw goat's milk ${ }^{13}$. The dry matter and fat value were found to be within acceptable levels for raw goat's milk.

The ewe's milk contained $\mathrm{pH} 6.69 \pm 0.02$, $0.21 \pm 0.01 \%$ titratable acidity (l.a.\%), dry matter $18.83 \pm 1.23 \%$, fat $5.80 \pm 1.21$, non-fat dry matter $13.03 \pm 1.71 \%$ and protein $6.39 \pm 0.08 \%$. The ewe's milk was within the reported mean values limits according to Turkish Standards for ewe's milk ${ }^{14}$.
Composition of cow's and goat's milk used in the study is very similar to each other. Ewe's milk samples in the dry matter, protein, fat and titratable acidity values were higher than other milks.

The results of the milk-clotting activity of different coagulants on raw and pasteurized cow's milk, goat's milk and ewe's milk are presented in Table 2.

Table 1: The chemical composition of raw cow's milk, goat's milk and ewe's milk

\begin{tabular}{lcccccc}
\hline Samples & $\mathbf{p H}$ & $\begin{array}{c}\text { Titratable } \\
\text { acidity }(\%)\end{array}$ & $\begin{array}{c}\text { Dry matter } \\
\mathbf{( \% )}\end{array}$ & $\begin{array}{c}\text { Fat } \\
\mathbf{( \% )}\end{array}$ & $\begin{array}{c}\text { Non-fat } \\
\text { dry matter (\%) }\end{array}$ & $\begin{array}{c}\text { Protein } \\
(\%)\end{array}$ \\
\hline Cow's milk & 6.76 & 0.18 & 11.72 & 3.30 & 8.42 & 4.40 \\
& 6.77 & 0.18 & 11.54 & 3.40 & 8.14 & 3.85 \\
& 6.77 & 0.17 & 11.62 & 3.40 & 8.22 & 3.92 \\
Goat's milk & $6.77 \pm 0.01$ & $0.18 \pm 0.01$ & $11.63 \pm 0.09$ & $3.40 \pm 0.06$ & $8.23 \pm 0.14$ & $4.06 \pm 0.30$ \\
& 6.78 & 0.15 & 12.29 & 3.80 & 8.49 & 4.27 \\
& 6.76 & 0.15 & 12.82 & 3.90 & 8.92 & 4.23 \\
Ewe's milk & $6.77 \pm 0.01$ & $0.15 \pm 0.00$ & $12.56 \pm 0.27$ & $3.83 \pm 0.06$ & $8.73 \pm 0.22$ & $4.26 \pm 0.04$ \\
& 6.70 & 0.21 & 17.62 & 6.50 & 11.12 & 6.46 \\
& 6.67 & 0.22 & 20.08 & 6.50 & 13.58 & 6.30 \\
& 6.69 & 0.21 & 18.80 & 4.40 & 14.40 & 6.41 \\
\hline
\end{tabular}

Table 2: The milk-clotting activity of different coagulants on raw and pasteurized cow's milk, goat's milk and ewe's milk

\begin{tabular}{lccc}
\hline Milk & Coagulants & \multicolumn{2}{c}{ Milk clotting activity } \\
& & $\begin{array}{c}\text { Raw } \\
\text { milk }\end{array}$ & $\begin{array}{c}\text { Pasteurized } \\
\text { milk }\end{array}$ \\
\hline Cow's milk & C1 & 3396 & 1033 \\
& C2 & 2717 & 5142 \\
& C3 & 3602 & 4472 \\
Goat's milk & C4 & 2466 & 3400 \\
& C2 & 2937 & 3157 \\
& C3 & 3179 & 5123 \\
& C4 & 2128 & 3728 \\
Ewe's milk & C1 & 5135 & 4570 \\
& C2 & 5014 & 6535 \\
& C3 & 5011 & 4656 \\
& C4 & 3535 & 4504 \\
\hline
\end{tabular}

\section{Effect on cow's milk}

The C3 sample had the highest milk clotting activity on raw and pasteurized cow's milk. However, C4 and C1 had the lowest milk clotting activity on raw cow's milk and pasteurized cow's milk, respectively. Milk clotting activity of pasteurized cow's milk was determined higher than that of raw cow's milk for C2, C3 and C4 samples. According to Egitoa et. al. (2007), specific clotting activity of albizia seed extract was 15 times higher than that of sunflower seed extract ${ }^{15}$.

\section{Effect on goat's milk}

The highest milk clotting activity was found in C3 for raw goat's milk and C2 for pasteurized goat's milk. Similar to cow's milk results, C4 and C1 samples had also the lowest milk clotting activity on raw goat's milk and pasteurized goat's milk, respectively. All coagulant samples had higher milk clotting activity on pasteurized goat's milk than milk clotting activity on raw goat's milk. The 
work by Dayisoylu et al. (2004) on the coagulating time of Ficus carica L. latex was depend on heat treatment for goat's milk and it takes between 3 and 5 minutes ${ }^{16}$.

\section{Effect on ewe's milk}

Milk clotting activity was detected at higher levels in C1 coagulant for raw ewe's milk and C2 coagulants for pasteurized ewe's milk. C4 sample have showed the lowest milk clotting activity on raw ewe's milk and pasteurized ewe's milk. Milk clotting activity of pasteurized ewe's milk was found higher for $\mathrm{C} 2$ and $\mathrm{C} 4$ coagulants. The coagulation of ewe's milk was studied by using different plant source coagulants and the end coagulation time was achieved very rapidly for milk clotted by Ficus carica L. ${ }^{17}$.

The highest milk clotting activity of all coagulant samples were found in raw ewe's milk, followed by raw cow's milk in C1, C3, C4 and raw goat's milk in $\mathrm{C} 2$. On the other hand, similar result was observed for pasteurized ewe's milk. The higher milk clotting activity of pasteurized cow's milk was determined in sample C2, C3, C4, followed by that of goat's milk was found in sample C1. Konar et al. (1990) were reported that coagulating effects of Ficus carica L. latex varied with the type of milk, being the minimum with the cow's milk and maximum with the goat's milk ${ }^{18}$. Similar result was reported by Dayısoylu et al. (2004) comparison of goat's milk and cow's milk coagulation time showed that cow's milk takes approximately three times longer than goat's milk $^{16}$.

This study in conclusion, revealed that four different coagulants had a strong coagulating effect on raw and pasteurized ewe's milk. The highest milk clotting activity of all coagulant samples were seen in ewe's milk, followed by cow's milk and goat's milk. Traditional farmhouse cheese coagulant's activity has not previously been studied by other researchers so, the present study may be considered as useful data for further research into this type of coagulant. Besides, additional work is necessary and may be useful for the complete characterization of traditional Tulum cheese produced using of this coagulant.

\section{REFERENCES}

1. FAO. Statistical year book. Food \& Agriculture Organization, http://www.fao.org (2013)

2. Say D, Soltani M and Güzeler N. Dairy Products Made from Sheep and Goat's Milk in Turkey. International Dairy Federation International Symposium on Sheep, Goat \& non-Cow Milk, 16-18 May 2011, Athens, Greece, p.73-76:(2011).

3. Vioque M, Go'mez R, Sanchez E, Mata C, Tejada L, and Fernandez-Salguero J. Chemical and Microbiological Characteristics of Ewes' Milk Cheese Manufactured with Extracts from Flowers of Cynara cardunculus and Cynara humilis as Coagulants. J. Agric. Food Chem.; 48:451-456:(2000).

4. Tavaria F. K, JoseÂ Sousa M and Xavier Malcata, F. Storage and Lyophilization Efects of Extracts of Cynara Cardunculus on the Degradation of Ovine and Caprine Caseins. Food Chemistry; 72:79-88: (2001).
5. Chazarra S, Sidrach L, Lopez-Molina D and Neptuno Rodrýguez-Lopez J. Characterization of the Milk-clotting Properties of Extracts from Artichoke (Cynara scolymus, L.) Flowers. International Dairy Journal; 17:13931400:(2007).

6. Jacob M, Jaros $D$ and Rohm H. Recent Advances in Milk Clotting Enzymes. International Journal of Dairy Technology; 64:1:(2011).

7. AOAC. Official Methods of Analysis of AOAC International. 16 th edn. Gaithersburg, USA:AOAC; (1995).

8. IDF. Milk, Cream and Evaporated MilkDetermination of Total Solids Content (Reference mehod). IDF 021. Brussels: International Dairy Fedaration:2010.

9. IDF. Milk-Determination of Fat Content. IDF 226. Brussels: International Dairy Fedaration:2008. 
10. IDF. Milk-Determination of Nitrogen ContentPart 1:Kjeldahl method. IDF 020-1. Brussels: International Dairy Fedaration:1993.

11. Anonymous. TS 3844 Cheese Rennet Standard. Turkish Standards Institute. Necatibey Caddesi, 112 Bakanlýklar, Ankara, p. 8 (1996).

12. Anonymous. TS 1018 Cow Milk-Raw Standard. Turkish Standards Institute. Necatibey Caddesi, 112 Bakanlýklar, Ankara, p. 13 (2002a).

13. Anonymous. TS 11046 Goat Milk-Raw Standard. Turkish Standards Institute. Necatibey Caddesi, 112 Bakanlýklar, Ankara, p. 7(2002b).

14. Anonymous. TS 11044 Ewe Milk-Raw Standard. Turkish Standards Institute. Necatibey Caddesi, 112 Bakanlýklar, Ankara, p. 7 (2002c).
15. Egitoa A. S, Girardetc J. M, Lagunaa L. E, Poirson C, Molle D, Micloc L, Humbert G, and Gaillardc J-L. Milk-clotting activity of enzyme extracts from sunflower and albizia seeds and specific hydrolysis of bovine k-casein. International Dairy Journal; :816825:(2007).

16. Dayısoylu K. S, Duman A. D, Gezginç $Y$ and Akyol I. Kahramanmara ${ }^{\circ}$ Region Fermented Milk Product:Teleme. Tradional Food Congress, 23-24 September, Van, p. 412-416: (2004).

17. Bornaz S, Guizani N, Fellah N, Sahli A, Slama M. B and Attia H. Effect of Plant Originated Coagulants and Chymosin on Ovine Milk Coagulation. International Journal of Food Properties; 13:10-22:(2010).

18. Konar A, Düzenli A and Uygun Z. Coagulating Effects of Some Plant Originated Enzymes on Various Milks. Cukurova University Journal of Faculty Agriculture; 5(1): 149-159:(1990) 